\title{
ANALISIS IMPLEMENTASI PROGRAM JAMINAN PERSALINAN DI PEMERINTAH DAERAHKOTA TANJUNGBALAI TAHUN 2019
}

\author{
Oleh: \\ Heri Rahman ${ }^{1)}$ \\ Matius Bangun ${ }^{2)}$ \\ Universitas Darma Agung, Medan ${ }^{1,2)}$ \\ E-mail : \\ anasthetiseri.hr@gmail.com $^{1)}$ \\ udastudi28@gmail.com ${ }^{2)}$
}

\begin{abstract}
Law of the Republic of Indonesia No.36 of 2009 concerning Health, article 17 paragraph 1 states that the government is responsible for the availability of access to information, education and health service facilities, one of which is the Maternity Insurance Program (Jampersal). This is what researchers do about how it is implemented in the Municipality of Tanjungbalai, North Sumatra. Implementation evaluation is carried out on the objectives, accountability and input provided for improvement in the future. The results showed that the implementation of childbirth insurance in Tanjungbalai City has not been running optimally so it needs improvement in the future both in structural synergy, namely the relationship between central and regional as well as in harmony, namely functionally between other related agencies in the Tanjungbalai City Government. From the SWOT analysis carried out, namely analyzing the Internal Strengths and Weaknesses and the External Opportunities and Threats factors, it shows the position of the Tanjungbalai City Government is in Quadrant I (first) with an Aggressive Strategy, namely using existing strengths to take advantage of the opportunities available.
\end{abstract}

Keywords: Evaluation, Implementation, Policy, Guarantee, Birth.

\begin{abstract}
ABSTRAK
Undang-undang RI No.36 Tahun 2009 tentang Kesehatan, pasal 17 ayat 1 menyebutkan bahwa pemerintah bertanggung jawab atas ketersediaan akses terhadap informasi, edukasi dan fasilitas pelayanan kesehatan yang salah satu jenis pelayanan tersebut adalah Program Jaminan Persalinan (Jampersal). Hal inilah yang dilakukan oleh peneliti tentang bagaimana implementasinya di Kota Tanjungbalai Sumatera Utara. Evaluasi implementasi di lakukan terhadap tujuan, akuntabilitas serta masukan yang diberikan untuk perbaikan di masa yang akan datang. Hasil penelitian menunjukkan pelaksanaan Jaminan Persalinan di Kota Tanjungbalai belum berjalan optimal sehingga perlu perbaikan perbaikan di masa yang akan datang baik secara sinergitas struktural yaitu hubungan antara pusat dan daerah maupun secara harmonitas fungsional antara instansi terkait lainnya di Pemerintah Kota Tanjungbalai. Dari analisis SWOT yang di lakukan yaitu menganalisis faktor Kekuatan dan Kelemahan secara Internal dan faktor Peluang dan Ancaman secara Eksternal menunjukkan posisi Pemerintah Kota Tanjungbalai berada pada Kwadran I (pertama) dengan Strategi Agresif yaitu menggunakan Kekuatan yang ada dalam memanfaatkan peluang yang tersedia.
\end{abstract}

Kata Kunci : Evaluasi, Implementasi, Kebijakan, Jaminan, Persalinan.

\section{PENDAHULUAN}

UU Republik Indonesia Nomor .36 / 2009 tentang Kesehatan, pada pasal 17 ayat 1 yang kemudian menyebutkan bahwa pemerintah bertanggung jawab atas ketersediaan akses terhadap informasi, edukasi dan fasilitas pelayanan kesehatan. Kemudian dilanjutkan sebagaimana tercantum pada Pasal 169 bahwa pemerintah juga memberikan kemudahan 
kepada masyarakat untuk memperoleh akses terhadap informasi kesehatan dalam upaya meningkatkan derajat kesehatan masyarakat.

Salah satu jenis pelayanan tersebut adalah Program Jaminan Persalinan (Jampersal) yang bertujuan untuk memberikan kemudahan dan keringanan bagi para ibu ibu selama kehamilan dan pasca melahirkan. Kebijakan tentang Jampersal tersbut tentu perlu terus di evaluasi agar semakin mendapatkan perbaikan baik dari aspek administrasi maupun teknis.

Demikian halnya di Pemerintah Kota Tanjungbalai yang telah mendapatkan dana Program jaminan Persalinan tersebut melalui Dana Alokasi Khusus (DAK) tentu dalam pelaksanannya terdapat permasalahn yang senantiasa memerlukan evaluasi pelaksanaannya. Diharapkan dari hasil evaluasi terhadap implementasi tersebut akan didapatkan data dan informasi yang lebih akurat sehingga apa yang menjadi tujuan program ini tercapai.

Berdasarkan uraian diatas, maka peneliti tertarik untuk membahasnya melalui penelitian dalam bentuk tesis dengan judul "Analisis Implementasi Program Jaminan Persalinan di Pemerintah Daerah Kota Tanjungbalai Tahun 2019”

Rumusan Masalah

Berdasarkan latar belakang tersebut maka Rumusan masalah adalah sebagai berikut :

a. Bagaimana implementasi kebijakan Jampersal di Pemko Tanjungbalai Tahun 2019?

b. Bagaimana Strategi peningkatan pelayanan Jampersal yang lebih di masa yang akan datang di Pemerintahan Kota Tanjungbalai.

\section{Tempat / Waktu Penelitian}

Penelitian ini dilakukan tempat utama adalah di Kantor Dinas Kesehatan Kota Tanjungbalai, beralamat di Jl. Gereja No. 2B, Kel. Karya, Kec. Tanjungbalai Selatan, Kota Tanjungbalai, Propinsi Sumatera Utara Kode pos 21311 dan tempat atau lokasi yang berhubungan dengan pelaksanaan Jampersal seperti di puskesmas, kecamatan dan kelurahan. Adapun waktu Penelitian ini dilaksanakan mulai bulan Juni sampai September 2020.

\section{Tujuan / Manfaat penelitian}

Berdasarkan hasil Rumusan Masalah tersebut, maka tujuan penelitian yang adalah :

a. Menganalisis implementasi kebijakan Program Jaminan Persalinan di Pemerintah Kota Tanjungbalai Tahun 2019?

b. Menganalisis Strategi peningkatan pelayanan jaminan persalinan di Pemerintah Kota Tanjungbalai?

sedangkan manfaat nya adalah

a. Bagi peniliti sebagai bahan persyaratan untuk menyelesaikan study prgram Strata 2 pada program magister Ilmu Pemerintahan Universitas Darma Agung Medan.

b. Bagi instansi dan pihak lainnya hasil penelitian diharapkan bermanfaat untuk meningkatkan pengetahuan tentang Jampersal.

\section{TINJAUAN PUSTAKA Analisis}

Pengertian analisis sebagaimana di jelaskan oleh Sugiyono (2010 : 244) analisis adalah pekerjaan sulit sehingga setiap peneliti harus mencari sendiri metode yang dirasakan cocok dengan sifat penelitiannya. Jadianalisis terebut merupakan penguraian suatu pokok yang di lakukan secara sistematis dalam menentukan bagian, hubungan antar bagian serta hubungannya secara keseluruhan untuk memperoleh pengertian ser pemahaman yang tepat.

\section{Kebijakan Publik}

William N Dunn 2003: 609 menambahkan bahwa salah satu tujuan dari kebijakan adalah yang berhubungan dengan metode analisis kebijakan untuk memudahkan mendapatkan informasi yang cepat dalam proses pengolahan data untuk 
kepentingan pengambilan keputusan. Sementara itu menurut Brewer dalam Study Public Policy, bahwa proses kebijakan terdiri atas 6 tahap: a. permulaan/ penanaman (invensi), $b$. estimasi (perkiraan), c. seleksi (pemilihan), d. implementasi (penerapan), e. evaluasi (penilaian) dan e. erminasi (penyelesaian).

Sementara itu Anderson (dalam Ekowati 2005:5) mengatakan bahwa kebijakan publik adalah kebijakan yang dikembangkan oleh badan-badan pejabatpejabat pemerintah. Selanjutnya diungkapkan bahwa implikasi dari definisi atau pengertian ini adalah: a) bahwa kebijakan itu selalu mempunyai tujuan tertentu atau tindakan yang berorientasi pada maksud dan tujuan. b) bahwa kebijakan itu pada hakekatnya berisi tindakan-tindakan atau pola tindakan Pemerintah/ Pejabat pemerintah, c) bahwa kebijakan itu merupakan apa yang sesungguhnya benar-benar dilakukan Pemerintah bahwa kebijakan itu berdasarkan pada peraturan atau perundang-undangan yang bersifat memaksa.

Demikian halnya seperti apa yang disampaikan Moenir (2010:11) bahwa pelayanan publik pada dasarnya adalah kegiatan ataupun rangkaian kegiatan atau tahapan dalam rangka pemenuhan kebutuhan pelayanan msyarakat sesuai dengan peraturan perundang-undangan bagi setiap warga Negara atas barang, jasa, dan/ atau pelayanan administratif yang disediakan oleh penyelenggara pelayanan masyarakat /publik. Sementara itu sebagaimana yang tertuang dalam Kepmen Pendayagunaan Aparatur Negara (PAN) Nomor ./KEP/25//M.PAN/2/2004 Pelayanan publik adalah kegiatan pelaksanaan yang dilaksanakan oleh penyelenggara pelayanan publik sebagai upaya pemenuhan kebutuhan akan pelayanan, maupun dalam rangka pelaksanaan ketentuan peraturan perundang-undangan.

\section{Evaluasi Implementasi}

Selain pengertian analisis, pelayanan publik, dan kebijakan publik maka dalam penelitian ini juga sangat urgen tentang pengertian Evaluasi. Sudjana (2006:48) menyatakan setidaknya terdapat enam hal tujuan evaluasi yaitu untuk : a) memberikan masukan masukan bagi perencanaan / program; b) menyajikan masukan masukan bagi pengambil keputusan yang berkaitan dengan tindak lanjut kegiatan dan program; c) memberikan masukan bagi pengambil keputusan tentang modifikasi, koreksi atau perbaikan program.

Pada umumnya evaluasi dilakukan setelah kebijakan publik tersebut diimplementasikan. Hal ini dilaksanakan tentunya dalam rangka menguji tingkat kegagalan dan keberhasilan, serta keefektifan dan keefisienan kebijakan tersebut. Abdulkahar Badjuri dan Teguh Yuwono (2002:132) berpendapat bahwa Evaluasi kebijakan setidak-tidaknya dimaksudkan untuk memenuhi tiga tujuan utama, yaitu: a. untuk menguji apakah suatu kebijakan yang teah diimplementasikan sudah sesuai atau mencapai tujuannya, b. menunjukkan bentuk akuntabilitas / pertanggung jawaban kepada publik tentang kebijakan yang telah diimplementasikan dan c. untuk memberikan masukan pada kebijakankebijakan publik yang akan datang.

Setelah penegertian evaluasi maka dalam penelitian tentang jaminan Persalinan ini dititikberatkan pada Evaluasi Implementasi.Menurut Mulyadi (2015:12), implementasi mengacu pada suatu tindakan untuk mencapai tujuantujuan yang telah ditetapkan sebelumnya dalam suatu keputusan. Tindakan tersebutberupaya berusaha untuk mengubah keputusan-keputusan yang akan menjadi pola-pola operasional serta berusaha mencapai perubahanperubahan besar atau kecil sebagaimana yang telah diputuskan sebelumnya.

\section{Sinergitas / Harmonitas}

Pada penelitian ini di bedakan pengertian sinegitas dan harmonitas. 
Sinegitas adalah keterpaduan akan peraturan secara vertikal dari instansi pusat dan daerah sementara harmonitas adalah keterpaduan secara Horizontal yaitu stakeholder yang ada lintas sektoral di PemkoTanjungbalai.Adanya interaksi antar stakeholders dan perlu adanya sinergi antar pemangku kepentingan. Najiyati dan Rahmat (2011) mengartikan sinergi sebagai kombinasi atau paduan antara unsur atau bagian yang dapat menghasilkan keluaran lebih baik dan lebih besar. Jadi sinergi tersebut dapat dipahami sebagai operasi gabungan atau perpaduan unsur untuk menghasilkan output yang lebih baik. Sedangkan definisi harmonisasi menurut Business Distionary bahwa harmonisasi adalah suatu instrument penyesuaian terhadap bentuk perbedaan dan penyesuaian terhadap ketidaksesuaian diantara ukuran yang berbeda, metode, prosedur, rencana, atau sistem yang membuat mereka menjadi seragam dan saling cocok.

\section{Penelitian Terdahulu}

Penelitian sebelumnya yang dilakukan oleh Gurendro. Putro (2013) tentang Analisis Implementasi Kebijakan Jaminan Persalinan Dalam Meningkatkan Cakupan Persalinan Tenaga Kesehatan di kabupaten Situbondo Tahun 2013, menunjukkan bahwa pada tingkat kepercayaan yang tinggi pada wanita hamil yang meminta bantuan persalinan $(92,5 \%)$ komitmen penyedia dalam menjalankan kebijakan Jampersal masih tinggi.

Miranti dkk (2015) dalam penelitiannya tentang Implementasi
Program JaminanPersalinan (Jampersal) di Puskesmas Jember Kidul Kecamatan Kaliwates, Kabupaten Jember menunjukkan bahwa dalam pelayanan Program Jampersal, Puskesmas Jember Kidul berupaya memberikan pelayanan kesehatan yang maksimal kepada masyarakat. Puskesmas Jember Kidul merupakan Puskesmas di Kabupaten Kaliwates dengan rating pengunjung sebesar 30.987 pengunjung dan pengunjung Jampersal terbanyak adalah pada periode Mei 2011 hingga April 2012 sebanyak 815 pengunjung. Berbeda dengan yang terjadi di Klinik Pemerintah Daerah lainnya yang rata-rata pengunjungnya sekitar 534 hingga 723 penerima Jampersal (Dinkes Jember, 2011-2012).

\section{KerangkaBerpikir}

Kerangka berpikir ini digunakan sebagai dasar atau acuan untuk menjawab pertanyaan-pertanyaan penelitian yang diangkat, atau bisa diartikan untuk mengalirkan jalan pikiran menurut kerangka logis (construct logic) atau kerangka konseptual yang relevan untuk menjawab terjadinya masalah. Untuk membuktikan kecermatan penelitian, dasar dari teori tersebut diperkuat dengan hasilhasil penelitian terdahulu yang relevan. Berikut kerangka berfikir sebagai berikut :

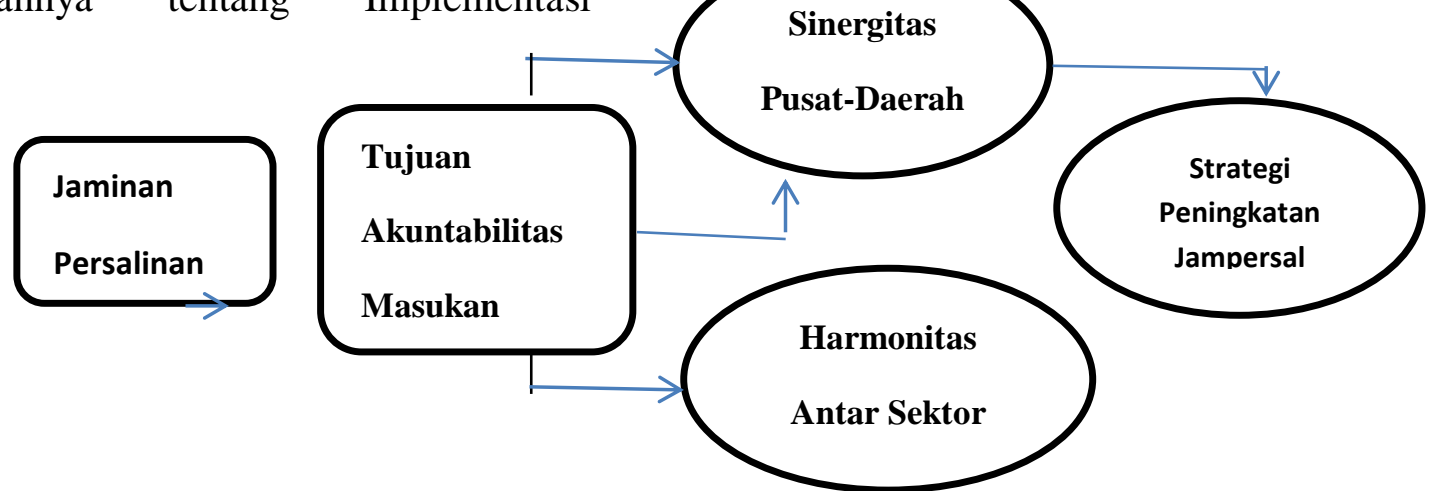

Gambar 1. Kerangka Berpikir Penelitian, 2020 


\section{METODE PELAKSANAAN}

a. Metode Penelitian

Adapun bentuk penelitian ini adalah kualitatif sesuai dengan rumusan dan tujuan penelitian, maka bentuk penelitian ini menitik beratkan pada proses, deskripsi analisis, yang bertujuan untuk mengetahui tentang Analisis Implementasi Program Jaminan Persalinan di Pemerintah Kota Tanjungbalai.

Sebagaimana yang di kemukakan oleh Kerd dan Miles (dalam Moleong, 2010:45) mendefinisikan bahwa penelitian kualitatif adalah tradisi atau kebiasaan tertentu dalam Ilmu Pengetahuan Sosial yang secara fundamental bergantung kepada pengamatan manusia dalam kawasan tersendiri dan berhubungan dengan orang-orang tersebut dalam bahasannya dan dalam peristilahannya.

b. Teknis Pengumpulan Data. Berdasarkan sumbernya dibedakan atas data Primer dan Sekunder. Data Primer dikumpulkan langsung dari sumber pertama sedangkan Data Sekunder adalah data yang sudah di publikasi dari instansi khususnya instansi pemerintah,

c. Analisis Data. Analisis Data yang diperoleh di lapangan dianalisis dengan menggunakan analisis deskriptif kualitatif yaitu menganalisis, menggambarkan, dan meringkas berbagai kondisi tertentu, situasi dan berbagai data yang dikumpulkan berrupa hasil wawancara atau pengamatan mengenai masalah yang diteliti yang terjadi di lapangan, I Made Winartha (2006).

- Analisa Delphi, Adiyatma (2018) Analisis Delphi adalah proses yang dilakukan dalam kelompok untuk mensurvei dan mengumpulkan pendapat dari para ahli terkait topik tertentu. Metode ini berguna untuk menstrukturkan pada proses komunikasi kelompok sehingga prosesnya akan berjalan efektif, sehingga kelompok tersebut bisa menyelesaikan masalahnya.

- Analisis Diskriftif tentang strategi peningkatan pelayanan jaminan Persalinan di Kota Tanjungbalai melalui kebijakan Edukasi, Informasi, penyediaan Fasilitas Kesehatan baik dari sinergitas Pusat - Daerah maupun harmonitas antar lintas sektoral.

- Analisis SWOT yaitu analisis yang di gunakan untuk menentukan strategi yang akan digunakan dalam melaksanakan pelayanan Jaminan Persalinan di Kota Tanjungbalai dengan menganalisis faktor Kekuatan dan Kelemahan secara internal serta Faktor yang menjadi Peluang dan Ancaman secara Eksternal..

\section{HASIL DAN PEMBAHASAN}

\section{TujuanJampersal}

Kepala Seksi yang menangani Jaminan Persalinan menyatakan bahwa dasar dari dilaksanakannya Jaminan Persalinan adalah Undang-undang RI No.36 Tahun 2009 tentang Kesehatan, pasal 17 ayat 1 menyebutkan bahwa pemerintah bertanggung jawab atas akses terhadap Edukasi, Informasi dan Fasilitas pelayanan kesehatan yang setinggitingginya. pada Pasal 17 ayat (1) ini merupakan konsen dalam penelitian ini tentang Evaluasi Implementasi yang dilakukan berdasarkan teori utama sebagaimana disebutkan oleh Abdulkahar B. dan Teguh Y. (2002:132) tentang Evaluasi yang dapat di lihat dari 3 indikator yaitu a. Tujuan Kebijakan, b. Akuntabilitas Kebijakan serta c. Masukan yang di berikan untuk kebijakan yang akan datang.

Kemudian kepala Dinas Kesehatan sebagai nara sumber kunci menambahkan Demikian juga pada pasal 168 ditekankan 
kembali bahwa untuk menyelenggarakan upaya atas kesehatan yang efektif dan efisien diperlukan berbagai Informasi Kesehatan yang dilakukan melalui kerjasama lintas sektor. Jadi meskipun hal tersebut adalah tentang kesehatan tapi sektor ini juga harus di dukung oleh sektor sektor lain khususnya yang berhubungan dengan kesehatan seperti perekonomian, tenaga kerja, lingkungan hidup dan lain sebagainya. Sedangkan pada pasal 169 dari Undang Undang tentang kesehatan ini disebutkan bahwa pemerintah memberikan berbagai kemudahan kepada masyarakat untuk memperoleh akses terhadap informasi kesehatan tersebut dalam upaya meningkatkan derajat kesehatan masyarakat.

Pelaksanaan Program Jaminan

Persalinan di Kota Tanjungbalai dalam kurun waktu lima (5) tahun terakhir ini belum menunjukan hasil yang optimal. Hal ini terlihat dari beberapa aspek seperti kurangnya pemahaman dan keterampilan yang dimiliki oleh Tim Pelaksana Jampersal atas pelaksanaan di lapangan. Untuk itu diperlukan upaya-upaya peningkatan kualitas sumber daya manusia dimana hasil kunjungan pada tahun 2019 yang lalu hanya 247 pasien saja.

\section{a. Edukasi}

Dari hasil wawancara dengan informan kunci baik Kepala Dinas Kesehatan dan Kepala Seksi yang membidangi masalah Jaminian Persalinan bahwa faktor Edukasi ini perlu senantiasa ditingkatkan. Dalam hal ini Dinas Kesehatan Kota Tanjungbalai memiliki keterbatasan dalam pelaksanaan sosalisasi yang sangat terbatas dalam memfasilitasi kegiatan yang dilakukan oleh pusat maupun propinsi.

b. Informasi.

Dari penjelasan informan diatas maka peneliti melihat bahwa untuk pengawasan dan pengendalian pelayanan jaminan persalinan dibentuklah tim verifikasi kelengkapan berkas administrasi sebagai syarat mutlak dalam penggunaan program jaminan persalinan di Kota Tanjungbalai untuk penjaringan dan kelayakan pasien-pasien menggunakan fasilitas jaminan persalinan tersebut dan dilaporkan kepada tim pelaksana Dinas Kesehatan Kota Tanjungbalai dan pihak-pihak terkait.

c. Fasilitas Pelayanan

Sarana kesehatan yang ada di Kota Tanjungbalai selain Puskesmas dan Puskesmas Pembantu juga terdapat sebuah Rumah Sakit Umum milik pemerintah yaitu Rumah Sakit Umum Daerah Kota Tanjungbalai. Selain RSUD, di Tanjungbalai juga terdapat 1 Rumah Sakit Swasta dengan jumlah tempat tidur 115 di RSUD dan 50 tempat tidur di rumah sakit swasta. Rumah Sakit Umum Daerah Kota Tanjungbalai telah diakreditasi dan mendapatkan nilai akreditas Dasar sedangkan Rumah Sakit Swasta Hadi Husada juga sudah diakreditasi dan juga mendapatkan nilai akreditasi Dasar.

d. Upaya Masyarakat

Pelaksanaan kegiatan pembangunan kesehatan perlu melibatkan peran serta masyarakat. Berbagai upaya dapat dilakukan dengan memanfaatkan potensi dan sumber daya yang ada di masyrakat. Posyandu adalah salah satu upaya kesehatan bersumber daya masyarakat yang menyelenggarakan minimal 5 (lima) program prioritas yaitu : a) Kesehatan Ibu dan Anak, b) Keluarga Berencana, c) perbaikan gizi, d) imunisasi dan f)penanggulangan diare.

Untuk memantau perkembangannya, posyandu dikelompokkan 4 strata yaitu Pratama, Madya, Purnama dan Mandiri. Ada empat kriteria penggolongan Posyandu tersebut yaitu jumlah kader, frekuensi kegiatan selama setahun, pencapaian kegiatan dan adanya program tambahan selain program dasar. 


\section{Akuntabilitas Kebijakan.}

Kepala seksi yang menangani jaminan Persalinan menjelaskan bahwa dalam rangka akuntabilitas (pertanggung jawaban) yang dilakukan adalah Ketaatan memberikan Laporan secara Berkala yaitu Laporan Bulanan, Triwulan, Semester dan Tahunan. Disamping secara Berkala juga disampaikan Laporan secara Insidentil bagi pihak pihak yang memerlukan khususnya Dewan Perwakilan rakyat daerah (DPRD) Kota Tanjungbalai. Berdasarkan penjelasan Informan tambahan tersebut bahwa kegiatan Dana Alokasi Khusus (DAK) menunjukkan bahwa laporan dalam bentuk aplikasi hanya diberikan kepada Pemerintah Pusat dan Sekretariat Daerah melalui bagian pemerintahan.

\section{Masukan Kebijakan}

Adapun masukan yang diberikan untuk perbaikan Kebijakan Jampersal di masa yang akan datang :

a. Tim Pelaksana Jaminan Persalinan agar diberikan Pelatihan Teknis.Diharapkan ditahun tahun berikutnya pelatihan ini dapat dialokasikan dari Dana Alokasi Desa (DAK) dan juga dibantu oprasional di lapangan oleh APBD Propinsi maupun APBD Kota Tanjungbalai.

b. Melibatkan instansi lintas Sektoral khususnya bagian Pemerintahan Seketariat Kota Tanjungbalai dan Kelurahan dengan terlibat langsung dalam Tim Pelaksana.

c. Agar diberikan dana Oprasional dari APBD Kota Tanjungbalai sebagai pendamping dari APBN DAK untuk mendukung kinerja Tim Pelaksana.

\section{Sinergitas dan Harmonitas}

Undang-undang RI No.36 Tahun 2009 tentang Kesehatan, pasal 17 ayat 1 menyebutkan bahwa pemerintah bertanggung jawab atas ketersediaan atas akses terhadap informasi, edukasi dan fasilitas pelayanan kesehatan. Ditambahkan pada Pasal 169 disebutkan bahwa pemerintah memberikan berbagai kemudahan kepada masyarakat untuk memperoleh akses terhadap informasi kesehatan dalam upaya meningkatkan derajat kesehatan masyarakat.

Undang-undang RI No.36 Tahun 2009 tentang Kesehatan, pasal 17 ayat 1 menyebutkan bahwa pemerintah bertanggung jawab atas adanya ketersediaan akses terhadap informasi, edukasi dan fasilitas pelayanan kesehatan. Dalam hal ini diperlukan harmonitas antara lintas sektoral yang ada di jajaran Pemko tanjungbalai.

\section{Strategi Peningkatan Pelayanan}

Berdasarkan studi Literatur dan Dokumen yang peneliti lakukan didukung dengan penjelasan para informan baik Informan Kunci maupun Informan Pendukung maka faktor faktor dalam Implementasi jampersal baik Internal (Kekuatan dan Kelemahan) maupun Eksternal (Peluang dan Ancaman) dapat dikelompokkan Internal sebagai berikut:

a. Faktor Internal. Analisis strategi faktor internal merupakan suatu penilaian terhadap faktor-faktor internal dari Kerjasama antar Daerah yang dilakukan yang mencakup sub sektor pertanian kekuatan maupun kelemahan yang dimiliki selanjutnya menyusun faktor-faktor tersebut kedalam tabel IFAS

(Internal

StrategicFactorsAnalysisSummary) dengan langkah-langkah sebagai berikut

1) Faktor Kekuatan :

- Adanya peraturan tentang jampersal

- Dukungan dana APBN dalam bentuk DAK 
- Potensi SDM pelaksana Jampersal

\section{2) Faktor Kelemahan}

- Belum adanya kesamaan pemahaman tentang Juknis Jampersal

- Belum terakomodasinya lintas sektoral dalam Tim Pelaksana,
- Rancunya isi dari Surat Keterangan Tidak mampu dari lurah setempat.

Jika faktor Kekuatan dan Kelemahan tersebut dianalisis dengan SWOT maka dapat dijabarkan hasilnya seperti berikut :

Tabel 1. Faktor Kekuatan dan Kelemahan dalam Jampersal, 2020

\begin{tabular}{|c|l|c|c|c|}
\hline No. & \multicolumn{1}{|c|}{ Kekuatan } & Bobot & Rating & Skor \\
\hline 1. & Adanya peraturan tentang Jampersal & $4(0,400)$ & 3 & 1.200 \\
\hline 2. & Dukungan dana APBN dalam DAK & $4(0.400)$ & 2 & 0.800 \\
\hline 3. & Potensi ADM melaksanakan Jampersal & $2(0,300)$ & 2 & 0.600 \\
\hline & Sub t o t a l & $\mathrm{A}=10.00$ & - & $\mathrm{B}=2.600$ \\
\hline No. & Kelemahan & Bobot & Rating & Skor \\
\hline 1. & Blm ada kesamaan pemahaman ttg Petunjuk Teknis & $3(0.375)$ & 1 & 0.375 \\
\hline 2. & Blm terakomodasi lintas sektoral dlm Tim Plaksana & $3(0.375)$ & 2 & 0.750 \\
\hline 3. & Rancunya SKTM dari Lurah setempat & $2(0.125)$ & 2 & 0.250 \\
\hline & sub total & $\mathrm{C}=8.00$ & - & $\mathrm{D}=1.375$ \\
\hline & T o t a l & $\mathrm{A}-\mathrm{C}=3.00$ & - & $\mathrm{B}-\mathrm{D}=1.225$ \\
\hline
\end{tabular}

Sumber : di olah oleh peneliti dari faktor Kekuatan dan Kelemahan Jampersal, 2020

b. Faktor Eksternal

Analisis faktor strategi eskternal merupakan suatu penilaian terhadap faktor-faktor eksternal dalam kerjasama antar daerah melalu kegiatan Atraksi, Aksesbilitas dan Amenitas terhadap geosite Kaldera Toba delam memberdayakan masyarakan lokal serta melestarikan keanekaragaman hayati Kaldera Toba.. Setelah mengetahui faktor-faktor eksternal tersebut sub sektor selanjutnya menyusun faktor-faktor tersebut kedalam tabel EFAS (ExternalStrategicFastorsAnalysisSum mary) dengan langkah-langkah sebagai berikut:

Tabel 2. Peluang dan Tantangan dalam melaksanakan Jampersal, 2020

\begin{tabular}{|c|l|c|c|c|}
\hline No. & \multicolumn{1}{|c|}{ Peluang } & Bobot & Rating & Skor \\
\hline 1. & Pelatihan teknis bagi Tim Pelaksana & $3(0.300)$ & 3 & 0.900 \\
\hline 2. & Kegiatan sosialisasi untuk lintas sektor & $3(0.300)$ & 3 & 0.900 \\
\hline 3. & Adanya dana APBD pendamping DAK & $4(0.400)$ & 3 & 1.200 \\
\hline & sub total & $\mathrm{A}=10.00$ & & $\mathrm{~B}=3.000$ \\
\hline No. & \multicolumn{1}{|c|}{ Ancaman } & Nilai & Bobot & Skor \\
\hline 1. & Perubahan Kebijakan pusat terhadap jampersal & $2(0.250)$ & 1 & 0.250 \\
\hline 2, & Gangguan psikologis akibat tekanan ekonomi & $4(0.500)$ & 2 & 1.000 \\
\hline 3. & Pengaruh wabah penyakit thp kesht / kehamilan & $2(0.250)$ & 2 & 0.500 \\
\hline & sub total & $\mathrm{C}=8.00$ & -- & $\mathrm{D}=1.750$ \\
\hline & To t a l & $\mathrm{A}-\mathrm{C}=2.00$ & & $\mathrm{~B}-\mathrm{D}=1.250$ \\
\hline
\end{tabular}

Sumber : diolah peneliti dari faktor Peluang dan Ancaman , 2020

Untuk menganalisis dari ke-dua tabel tersebut yaitu Faktor Internal dan Faktor Eksternal maka dapat diturunkan dalam bentuk Diagram SWOT yang telah didapat dari hasil analisis sebelumnya dikembangkan secara 
kuantitatif melalui perhitungan diagram analisis SWOT untuk mengetahui secara pasti posisi kerjasama antar daerah (KAD) yang sesungguhnya. Perolehan kedua angka hasil pengurangan tersebut kemudian dimasukan ke dalam diagram SWOT. Hasil pengurangan antara skor kekuatan dengan skor kelemahan dilelatakan di sumbu X yaitu Strength (Kekuatan) $=2$, Weakness (kelemahan) $=1,225$ sehingga di peroleh nilai 0.775 ; sedangkan hasil pengurangan antara skor peluang dengan skor ancaman diletakan di sumbu Y, yaitu Opportunity (peluang) $=2$ dan Treath (ancaman) 1.250 sehingga di peroleh titik 0,750. Dengan demikian pada posisi sumbu $X$ di peroleh titik 0.775 sedangkan pada sumbu $\mathrm{Y}$ di peroleh nilai 0.750 sehingga koordinat strategi berada pada titik $(0.775,0.750)$. Posisi titik yang didapatkan menggambarkan posisi strategi yang dilakukan pada peningkatan keberhasilan Jaminan Persalinan dengan Diagram sebagai berikut :

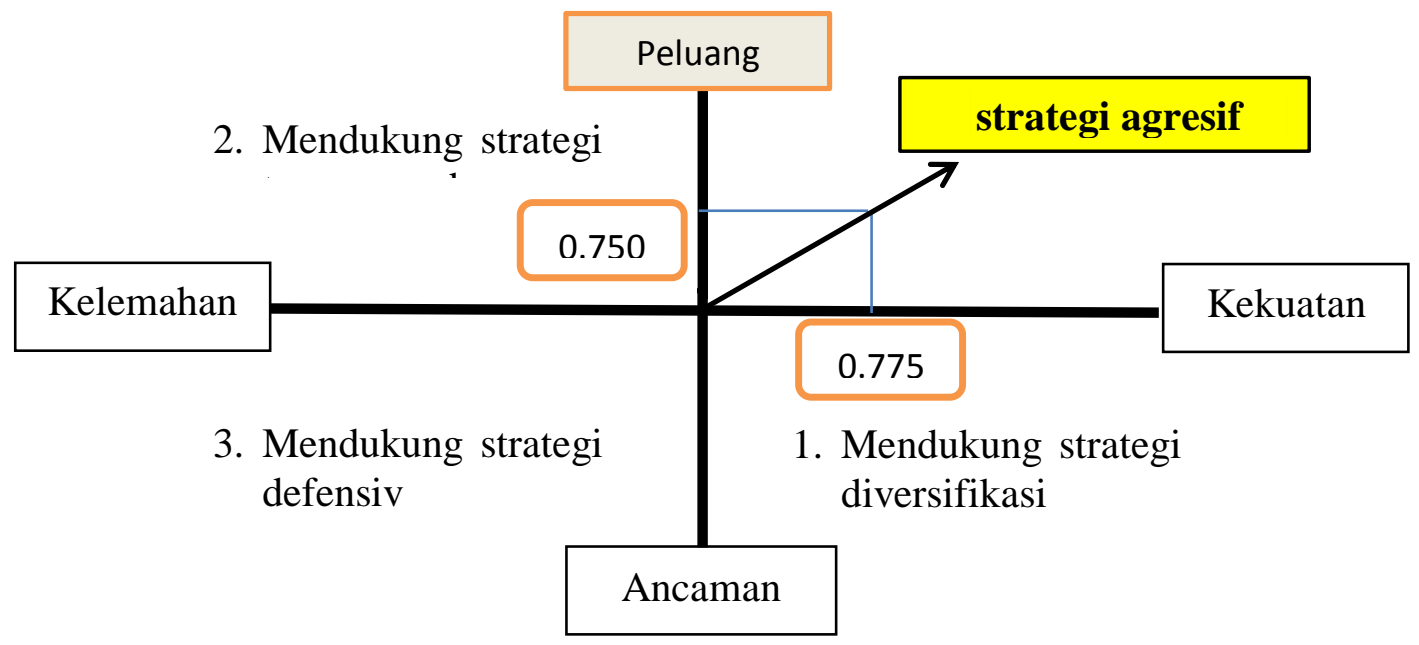

Gambar 1. Strategi SWOT Jampersal Kota tanjungbalai 2019.

Gambar diatas memperlihatkan analisis SWOT yaitu untuk mengevaluasi kekuatan (strengths), kelemahan (weaknesses), peluang (opportunities), dan ancaman (threats) dalam suatu kegiatan seperti kerjasama antar daerah. Dari Diagram tersebut di atas dapat dimaknai sebagai langkah dalam kebijakan yang akan ditempuh untuk memberhasilkan peningkatan Pelayanan jaminan Persalinan di Kota Tanjungbalai.

Adapun posisi berdasarkan analisis SWOT bahwa posisi diagram berada pada Kwadran I (Pertama) yang disebut dengan Strategi Agresif yaitu menciptakan strategi yang menggunakan Kekuatan dalam memanfaatkan Peluang.
Menggunakan kekuatan tersebut adalah menggunakan ketersediaan adanya peraturan tentang Jaminan Persalinan baik Undang Undang Kesehatan, Peraturan Menteri Kesehatan tentang Jaminan Persalinan, serta Peraturan Walikota tentang Tim Pelaksan jaminan Persalian; Tersediannya dukungan pendanaan dari Dana Alokasi Khusus dari APBN, potensi pengembangan sumber daya manusia (SDM) yang tersedia di Kota Tanjungbalai.

Menggunakan kekuatan tersebut sekaligus memanfaatkan peluang yang ada dimana hal tersebut diharapkan tertampung di APBD Kota Tanjungbalai dengan dukungan dari anggota DPRD Kota 
Tanjungbalia dan juga memanfaatkan peluang yang ada dari pemerintah provinsi.

\section{SIMPULAN}

\section{Simpulan}

Adapun kesimpulan dari penelitian tentang Implemtasi kebijakan program persalinan di Pemerintah yaitu: terdapat permasalahan sehubungan dengan terbatasnya sumber daya manusia khususnya dalam Tim Pelaksana, kekurangan personil khususnya dari Sekretarian Daerah dan Kelurahan, Surat Keterangan Tidak mampu (SKTM) yang dikeluarkan oleh lurahberdasarkan keterangan warga, pelayanan program Jaminan Persalinan tidak dilaksanakan oleh Puskesmas tapi di Praktek Bidan Swasta.

Strategi dalam peningkatan pelayanan Jaminan Persalinan di Kota Tanjungbalai adalah Strategi Agresif yaitu : Menggunakan kekuatan yaitu adanya peraturan tentang Jaminan Persalinan baik Undang Undang Kesehatan, Tersediannya dukungan pendanaan dari Dana Alokasi Khusus dari APBN, Potensi pengembangan sumber daya manusia (SDM) yang tersedia di Kota Tanjungbalai dalam memanfaatkan peluang yang ada tertampungnya dana pendamping APBD Kota Tanjungbalai dengan dukungan dari anggota DPRD Kota Tanjungbalia dan juga memanfaatkan peluang yang ada dari pemerintah provinsi.

\section{Saran}

Dari kesimpulan tersebut maka beberapa Rekomendasi dari hasil penelitian tentang Implementasi jaminan Persalinan di Kota Tanjungbalai adalah :

a) Untuk menanggulangi adanya keterbatasan sumber daya manusia khususnya dalam Tim Pelaksana dalam memahami pelaksanaan Jaminan Persalinan di Kota Tanjungbalai agar Kepala Dinas
Kesehatan mengusulkan anggaran untuk mengadakan pelatihan teknis terhadap Tim Pelaksanan Jaminan Persalinan tersebut.

b) Agar disosialisasikan pentingnya melengkapi Tim pelaksana khususnya dari Sekretarian Daerah dalam hal ini staf dari Bagian Pemerintahan dan dari kelurahan demi kelancaran pelaksanaan jaminan Persalinan.

c) Surat Keterangan Tidak mampu (SKTM) yang dikeluarkan oleh Lurah adalah berdasarkan hasil verifikasi dan validasi yang dilakukan oleh pihak Kelurahan dan bukan berdasarkan keterangan dari warga yang membutuhkan SKTM.

d) Ditingkat puskesmas adanya temuan bahwa pelayanan program jaminan persalinan tidak dilaksanakan sama sekali hanya dilaksanakan oleh Praktek Bidan Swasta, untuk itu diperlukan terus pembenahan baik sistem maupun materinya.

e) Ditingkat Dinas Kesehatan Kota Tanjungbalai adanya temuan bahwa para bidan dan pasien selalu mempertanyakan mekanisme penggunaan jaminan persalinan sehingga pelayanan public tidak berjalan dengan maksimal. Menyikapi hal ini agar selain sosialisasi oleh Tim pelaksana juga perlu informasi yang mudah diperoleh masyarakat dalam berbagai bentuk seperti baliho, liflet, poster dan lain sejenisnya baik di Kantor Dinas, Puskesmas maupun di Kelurahan.

\section{DAFTAR PUSTAKA}

\section{$\underline{B u k u-B u k u}$}

Abdul Wahab, Solichin, 2011. Analisis Kebijaksanaan: dari Formulasi ke Implementasi Kebijaksanaan Negara, Sinar Grafika, Jakarta

Ahmad Erani Yustika,2013. Industrialisasi Pinggiran, Pustaka Pelajar (Anggota. 
Aan Komariah, $\quad$ Djam'an Satori. 2014 Metodologi Penelitian Kualitatif. Bandung : Alfabeta.Agustino, Leo. 2019. DasarDasar Kebijakan Publik. Alfabeta: Bandung.Berman, Barry dan Evans, Joel R, (2004). Retail Management A Strategic. Apporoach. Ninth Editon. New Jersey. Pearson Education.

Moleong, Lexy.2014. Metode Penelitian Kualitatif , Edisi Revisi. PT Remaja Rosdakarya,.Bandung.

Daniel A and Paul A. Sabatier. 1983. Implementation and Public. Policy, Scott Foresman and Company, USA. Mcleod.

Najiyati, S dan Danarti. 2006. Kopi Budidaya dan Penanganan Lepas Panen.Penebar Swadaya, Jakarta.

Sondang P Siagian. 2016.Manajemen Sumber Daya Manusia.Jakarta: Penerbit: Bumi.

Sugiyono. (2014). Metode Penelitian Pendidikan Pendekatan Kuantitatif, Kualitatif, dan R\&D. Bandung: Alfabeta.

Widodo, Joko. 2011. Analisi Kebijakan Publik, Malang: Bayumedia Publishing.

Winarno, Budi, 2012. Kebijakan Publik: Teori dan Proses, PT. Buku Kita, Jakarta.

Ulber, Silalahi.2011. Asas Asas Manajemen. Bandung: Refika Aditama.

\section{Jurnal :}

1. Analisis Implementasi Kebijakan jaminan Persalinan dalam Meningkatkan Cakupan Persalinan Tenaga Kesehatan di KecaatanSitubundo 2019.

2. Implementasi Program Jaminan Persalinan (Jampersal) di Puskesmas Jember Kidul Kecamatan kaliwates Kabupaten Jember.

3. Gambaran Implementasi Program Jaminan Persalinan (Jampersal) Di Puskesmas Batua Kota Makasar (Makasar The Descritionof The ImplementasinoftheChildbirth

Assurance Service atClinicBatuaMakasar).

4. Implementasi Kebijakan Jaminan Persalinan (jampersal) di Puskesmas balida Kecamatan Dawuan kabupaten majalengka

\section{PeraturanPerundang Undangan}

a. Undang Undang Republik Indonesia Nomor 36 tahun 2009 tentang Kesehatan.

b. Kementerian Kesehatan RI Tahun 2011 Tentang jaminan pembiayaan pelayanan persalinan.

c. Juknis Nomor 09 Tahun 2019 tentang Dana Alokasi Khusus (DAK) Non FisikKota Tanjung Balai Tahun Anggaran 2019. 